\title{
Temporal structure of the peritrich ciliate assemblage in a large Neotropical lake
}

\author{
Lúcia SL Safi, Nelson F Fontoura, Henrique J Severo and Laura RP Utz*
}

\begin{abstract}
Background: Periphytic communities are usually composed by prokaryotic and eukaryotic microbes and small metazoans and could be found in any submerged surface in aquatic environments. Ciliates generally are the dominant organisms in periphytic communities where they can form assemblages of complex taxonomic composition. Among these ciliate taxa, peritrichs are very common organisms found in periphyton; also, they are easy to collect, be easily recognized, and have been widely used to evaluate and monitor ecological and ecotoxicological investigations. Several studies have been focused on periphytic communities in freshwaters from the Northern Hemisphere, with very little data on similar environments in the South. In the present study, we analyzed the structure and temporal dynamics of the ciliate peritrich community in a Neotropical shallow lake, comparing the fluctuation of the peritrich community with environmental factors.

Results: Peritrichia comprised a total of 22 morphospecies throughout the year with genera Epistylis and Vorticella the most diverse and abundant genera. Peritrich density was considerably higher during fall and winter, demonstrating a clear seasonal cycle. Small, solitary species showed no pattern of dominance during any particular stage of succession, reaching abundance peak any time during the sampling period. On the other hand, large colonial species were abundant only in the last half of each successional cycle. Species abundance was correlated to temporal and environmental drivers.

Conclusion: Our results support the hypothesis of a temporal pattern of succession in the community of peritrich ciliates that composes the periphyton of the studied lake with different responses by individual species to successional time, year, season, and environmental factors.
\end{abstract}

Keywords: Periphyton; Biofilm; Community; Subtropical; Pollution

\section{Background}

Submerged surfaces are usually colonized by complex communities of prokaryotic and eukaryotic microbes, which include bacteria, fungi, algae, protozoa, and small metazoans, forming a dynamic layer termed periphyton or biofilm (Wetzel 2001). This biofilm may represent the major proportion of bacterial biomass in natural or artificial ecosystems (Wey et al. 2008).

Among the most important factors controlling these bacterial communities is the grazing activities of protozoa (Wey et al. 2008). Ciliates, in particular, participate in a wide range of metabolic pathways in aquatic ecosystems, playing an essential role as predators of bacteria

\footnotetext{
* Correspondence: laura.utz@pucrs.br

Programa de Pós-Graduação em Zoologia, Faculdade de Biociências, Pontifícia Universidade Católica do Rio Grande do Sul, Av. Ipiranga 6681 Porto Alegre, RS 90619-900, Brazil
}

and other small planktonic species, recycling nutrients that support the whole trophic cascade in both marine and freshwater ecosystems (Beaver and Chrisman 1989; Jack and Gilbert 1997; Carrias et al. 2001; Andrushchyshyn et al. 2003; Zingel and Nõges 2010).

Peritrich ciliates (subclass Peritrichia) are very common organisms found in the periphytic communities, being also one of the most diversified group in the phylum Ciliophora, with more than 50 genera and 1,000 species described so far (Li et al. 2008; Lynn 2008). With easy sampling, recognition, and possible standardization for temporal and spatial comparisons, peritrich ciliates have been widely used to evaluate and monitor responses to contamination in ecological and ecotoxicological investigations (Gong et al. 2005; Xu et al. 2009).

In recent years, increased interest has focused on studies concerning the colonization and successional patterns of

\section{实}


biofilm communities on artificial substrates (Gong et al. 2005; Xu et al. 2009, 2011; Mieczan 2010). For example, Gong et al. (2005) studied biofilm ciliates from scallop farming waters of Jiaozhou Bay (China) and found 12 dominant species that presented a clear successional pattern over the year. Mieczan (2010) conducted a study on stems of Phragmites australis in freshwater habitats in Poland and observed that the abundance of biofilm ciliates was also correlated with environmental variables, but diverse responses were observed for different lakes. In a study of Korean coastal waters, $\mathrm{Xu}$ et al. (2009) identified 27 periphytic ciliates and observed a clear temporal pattern in the species succession.

Although there are several examples of studies focusing on identification, dynamics, and bioindication of periphytic microorganisms, most of them have been developed in the Northern Hemisphere. In the Southern Hemisphere, we recall few studies that tested toxicity of chemicals to periphyton, or composition of periphytic communities with emphasis on autotrophic microorganisms (Salomoni and Torgan 2008). No study so far has investigated peritrichs or other ciliates as components of periphytic communities in Brazil or in the Southern Hemisphere.

Thus, in the present work, we analyzed the structure and temporal dynamics of the peritrich community in a Neotropical shallow lake. We hypothesize that there is a fluctuation of the peritrich community over the year, and this fluctuation could be related to environmental variables. To test this hypothesis, we: (1) documented the taxonomic composition of free-living sessilid peritrichs, (2) described the population dynamics of numerically dominant species, and (3) analyzed possible correlation between species abundance and water chemical and physical parameters.

\section{Methods \\ Study area}

The Guaíba Lake is $50 \mathrm{~km}$ long and $20 \mathrm{~km}$ wide (Figure 1), with an average depth of $2 \mathrm{~m}$, but reaches $12 \mathrm{~m}$ in the navigation channel. Main tributaries are the rivers Jacuí, Caí, Sinos, Gravataí, Dilúvio, Salso, Itapuã, Petin, Ribeiro, and Araçá. On its northern boundary, the lake is delimited by the Jacuí Delta, comprising the rivers Jacuí, Sinos, Caí, and Gravataí, and a large number of sedimentary islands. On its southern boundary, Guaíba Lake drains (average $2,200 \mathrm{~m}^{3} \mathrm{~s}^{-1}$ ) to the large Patos Lagoon (250 km long), which presents an estuarine area and connects to the Atlantic Ocean (Rossato and Martins 2001; Martins et al. 2006).

There is a relatively dense human population in the areas surrounding Guaíba Lake, including the city of Porto Alegre (with more than 1.5 million inhabitants) and its suburbs. The lake is used for public water supply,

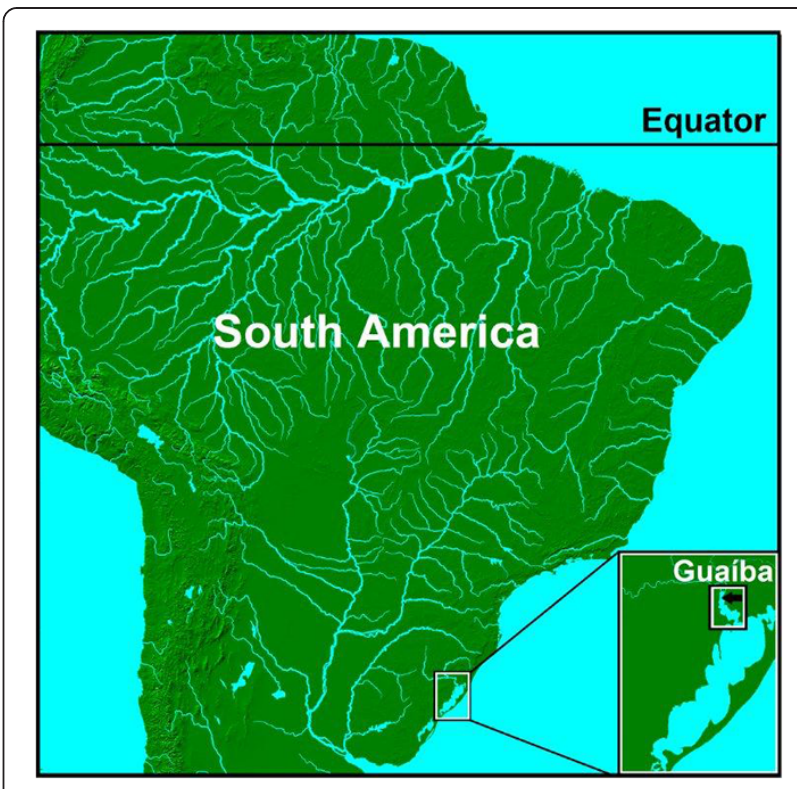

Figure 1 Sampling site: Guaíba Lake, Brazil (Clube dos Jangadeiros; $30^{\circ} 6^{\prime} 38^{\prime \prime} \mathrm{S}, \mathbf{5 1}^{\circ} 15^{\prime} 38^{\prime \prime} \mathrm{W}$ ). The black arrow points to the exact sampling site.

irrigation, tourism, recreation, shipping, and fishing, and also receives large amounts of domestic, agricultural, and industrial wastewater that compromise water quality. Its turbid waters (transparency $<1.1 \mathrm{~m} ; 40$ to 100 nephelometric turbidity unit (NTU)) range from mildly acidic ( $\mathrm{pH}$ 6.6) to basic ( $\mathrm{pH}$ 8.3) (Salomoni and Torgan 2008); the average BOD is $3 \mathrm{mg} \mathrm{L}^{-1} \mathrm{O}_{2}$, while the concentration of dissolved oxygen is usually $6 \mathrm{mg}$ $\mathrm{L}^{-1} \mathrm{O}_{2}$ (Bendati et al. 2000).

\section{Sampling}

Sampling was performed from a boat pier in northern Guaíba Lake (30 6 $38^{\prime \prime} \mathrm{S}, 51^{\circ} 15^{\prime} 38^{\prime \prime} \mathrm{W}$; Figure 1, black arrow). The peritrich community was sampled using a set of 30 glass microscope slides, arranged in 15 pairs (two slides joined together by a clamp) and suspended at a depth of $30 \mathrm{~cm}$ from a floating device. Each sampling series was initiated at the beginning of each year season (2010 sampling program: June 21 winter, September 23 spring, December 21 summer; 2011 sampling program: March 20 fall). The sampling program began with daily removal of a pair of slides from the slide set for the first 5 days. After that, another set of slides was removed on the 10th, 15th, and 20th sampling days. After 20th day of sampling, two slides were removed at a 10-day interval until the end of each season (15 sampling data distributed along 90 days of the succession cycle). Once removed from the lake, the slides were placed into a plastic bottle with unfiltered water from the sampling site and taken immediately to a laboratory. 


\section{Sample analysis}

The two replicates taken from the field were analyzed in the laboratory using a CH30 RF 100 Olympus light microscope. Although not tested, the peritrich distribution on the glass slide did not show a visible pattern, so each glass slide was covered by a $22 \times 22$-mm cover slip placed on its middle, delimiting the analyzed area. The total number of colonies and zooids of all peritrich ciliates found in the observation area was recorded. Species richness and density were calculated as the average of the two sampled slides. For a more precise identification, some species were cultured in the laboratory. Individuals were removed from glass slides with forceps, placed in a Petri dish with $10 \mathrm{ml}$ of mineral water, fed with an infusion of wheat grass (Dagget and Nerad 1992), and kept at room temperature. The Protargol (Polysciences Europe $\mathrm{GmbH}$, Eppelheim, Germany) silver impregnation technique (Montagnes and Lynn 1987) was applied to the species that were cultured in the laboratory. Morphometric measurements were made on cultured and silver-stained organisms. Morphological characters such as length and width of the zooid at midpoint, length and width of the basal stalk, and size of the peristomial lip were measured. The shape and position of micro- and macronucleus were observed in living and impregnated cells. The species were identified based on the descriptions of Kahl (1935), reviews of Warren (1982, 1986, 1991), and on the work of Foissner et al. (1992). Morphological measurements were also used to compare morphologically diverse species to create a compound size value (the sum of the mean zooid length, the mean zooid width at midpoint, the mean basal stalk length, and width).

\section{Environmental parameters of water quality}

Once a week, during the entire study period, water temperature $\left({ }^{\circ} \mathrm{C}\right), \mathrm{pH}$, and conductivity $\left(\mu \mathrm{S} \mathrm{cm}{ }^{-1}\right)$ were measured. Other parameters such as chlorophyll $a\left(\mu \mathrm{g} \mathrm{L}^{-1}\right)$, total solids $\left(\mu \mathrm{g} \mathrm{L}^{-1}\right)$, dissolved oxygen $\left(\mathrm{mg} \mathrm{L}^{-1} \mathrm{O}^{2}\right)$, turbidity (NTU), and total phosphorous $\left(\mathrm{mg} \mathrm{L}^{-1} \mathrm{P}\right)$ were provided by the Research Center of the County Department of Water and Sewerage (DMAE), whose collections were performed monthly in the vicinity of the sampling site. Although biological and environmental samplings were not simultaneous due to logistic limitations, the objective was to identify general seasonal patterns of the environmental descriptors and how they could affect the peritrich community.

\section{Statistical analysis}

To identify general patterns of ciliate abundance in relation to environmental predictors, measured abundance was heavily transformed as follows. First, considering the exponential pattern of population growth, abundance was $\log$-transformed $(\ln (x+1))$ to seek for linear responses. Second, to allow a cleaner response effect, each value was standardized as standard deviations from the annual mean. This procedure favors the direct identification of the environmental drivers that increase or decrease abundance in relation to the annual mean. Also, considering extreme abundance values and loose of normality, values below -2 and above 2 were changed to -2 and 2, respectively. Abundance was then rescaled to relative abundance ( 0 to 1 ) by adding 2 and dividing by 4. Although all these procedures seems to disfigure the original data, our main objective was not to seek for predictive abundance models, but to identify general patterns of what environmental parameters contribute to increase or decrease each species abundance.

Patterns concerning temporal and environmental drivers for the peritrich community were identified by using principal component analysis (PCA; SPSS 17.0, Armonk, NY, USA). Multiple linear regressions (MLR) correlating relative abundance of each species with temporal and environmental parameters (winter, spring, summer, fall, days of exposure, temperature, $\mathrm{pH}$, chlorophyll $a$, total solids, dissolved oxygen, conductivity, turbidity, and total phosphorous) were performed using SPSS (version 17.0), with the Backward-Wald method and a $P$ value of $<0.3$ as the removal threshold. MLR was chosen instead of other multivariate methods because of the ability to measure the relative effect of each descriptor without the effect of other environmental drivers included in the model. From the MLR coefficients, a cluster analysis (SPSS, version 17.0) was used to identify patterns of species association. A new approach was applied as follows: Relative importance coefficient or $\mathrm{RIC}=(1-P) \times B / \bmod (B)$, where $P$ is the significance value for each regression coefficient $B$, and mod represents the modulus of the $B$ value. This approach, although unusual, carry an interesting attribute: the aggregation schedule will be governed both by the positive/negative effect of an environmental driver ( $B$ value signal) and the probability of the effect to be true (1 $-P$ value). The clustering tree was constructed using Euclidean distance as the association metric and Ward's aggregation method.

\section{Species diversity and constancy}

The Shannon-Wiener diversity index $\left(\mathrm{H}^{\prime}\right)$ was calculated for each sampling day throughout the entire study. Also, the number of occurrences of each species was divided by the total number of samples, which allowed species to be classified by the frequency of occurrence. Species that appeared in more than $50 \%$ of the collections were designated as 'constant'. Species considered 'accessory' were present in $25 \%$ to $49 \%$ of the samples, and if species were present in less than $25 \%$ of the collections, they were considered 'casual'. The species were also 
classified according to their successional stage by considering them to be pioneer if their maximum appearance in the samples occurred before the 30th day of sampling, secondary if their maximum appearances occurred between 30 and 60 days of exposure, and climax species if their maximum appearances occurred after the 60th day of exposure.

\section{Results}

\section{Environmental physical and chemical parameters}

Seasonal fluctuation of environmental parameters of water quality is presented in Figure 2. Observed values did not differ from those already reported by Bendati et al. (2000). Water temperature ranged from $12^{\circ} \mathrm{C}$ to $28.5^{\circ} \mathrm{C}$, and the values for dissolved oxygen were between 5.6 and $9.3 \mathrm{mg} \mathrm{L}^{-1}$. The $\mathrm{pH}$ ranged from 6.4 to 7.2 , and amounts of total suspended solids (TS) ranged from less than 10 to $42 \mathrm{mg} \mathrm{L}^{-1}$. Chlorophyll $a$ measurement ranged from undetected to $6.1 \mu \mathrm{g} \mathrm{L}^{-1}$, and turbidity from 17 to 85.4 NTU. Finally, total phosphorus (TP) and conductivity ranged between 0.09 and $0.19 \mathrm{mg} \mathrm{L}^{-1}$ and 72.5 and $84.05 \mu \mathrm{sm}^{-1}$, respectively.

A general pattern of environmental descriptors could be identified in Figure 3, a biplot distribution of components 1 and 2 from a PCA, explaining 55\% of total variance. Spring, summer, and water temperature were negatively related to component 1 , while although all other measured parameters were positively correlated and appeared on the

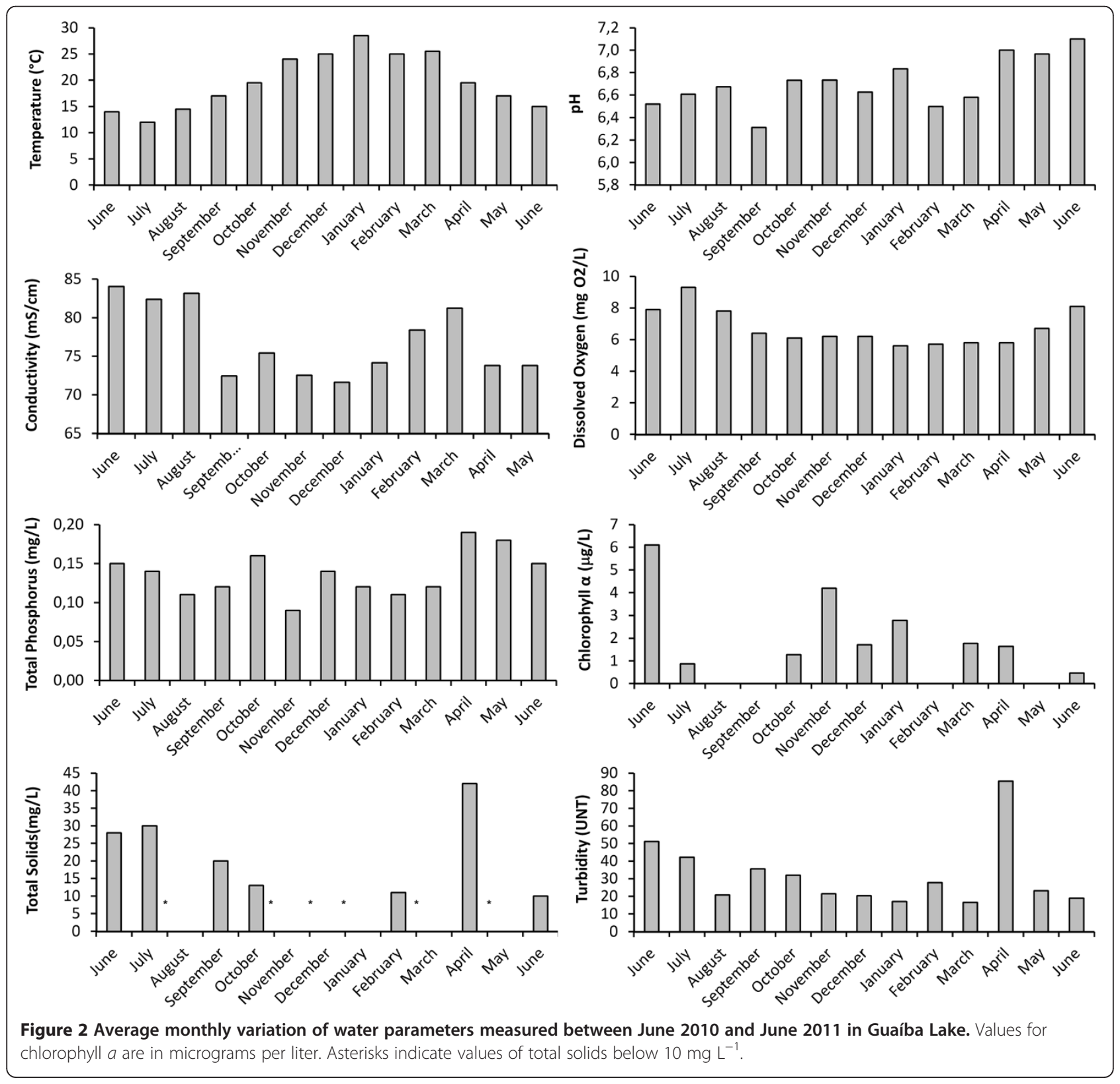




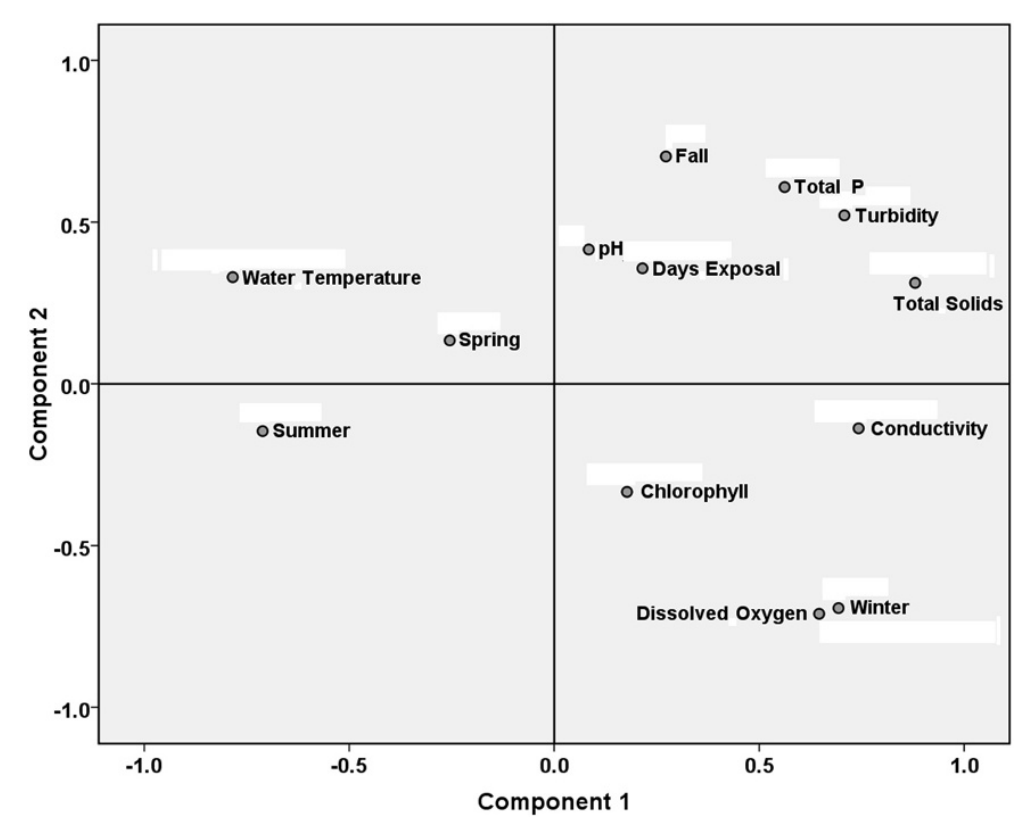

Figure 3 General patterns of environmental descriptors in Guaíba Lake, Brazil. Biplot from a principal component analysis (PCA) explaining $55 \%$ of total variance

right side of the diagram. Component 2 detach fall and winter, with fall associated to total phosphorous, total solids, turbidity, $\mathrm{pH}$, and days of exposal. Winter group was associated with increased dissolved oxygen.

\section{Abundance and species composition}

Peritrichs were recorded from the first or second day in each sampling cycle, comprising a total of 35 morphospecies throughout the year, although only 22 were identified at species or genus level and were included in the present data analysis. These species were identified based on morphological characters observed and measured in vivo and on the arrangement of oral polykinetids (OPKs) in Protargol-stained individuals. The configuration pattern of OPKs is considered species specific in peritrichs and widely used to tell apart different species in this subclass. Figure 4 shows the four Epistylis species identified only at the genus level. These four peritrich species found in the present study are apparently undescribed and will be described after further investigation.

Maximum species richness per season, considering the nominated species (Figure 5, blue line), ranged from 8 in
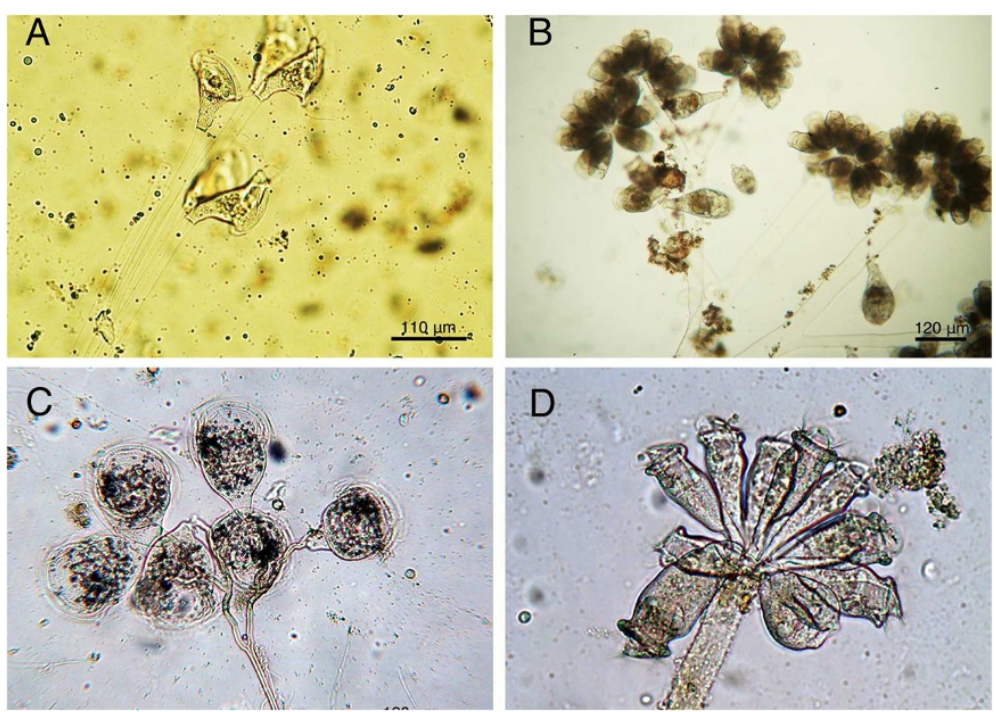

Figure 4 Non-identified species ofEpistylis. (A) Epistylis sp. 2, (B). Epistylis sp. 1, (C) Epistylis sp. 3, and (D) Epistylis sp. 4. 

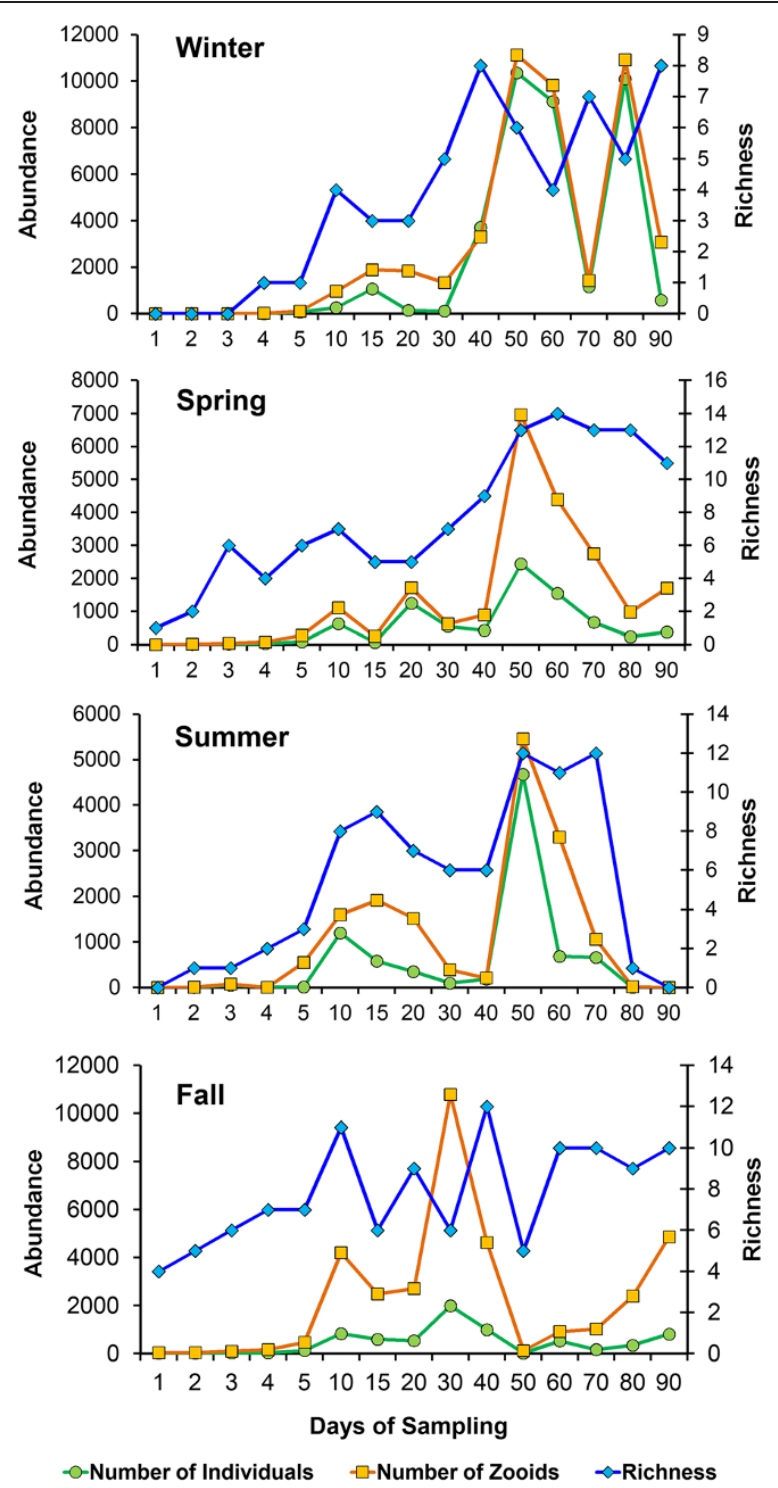

Figure 5 Individual and zooid abundance and richness of ciliates in Guaíba Lake, southern Brazil. The glass slide used is $22 \times 22 \mathrm{~mm}$ ).

winter to 14 in spring. Considering the succession cycle, species richness increased along each successional cycle, but at some points, it was observed that it markedly reduced, as at the end of summer.

Peak abundance of individual peritrichs (solitary cells + colonies; Figure 5, green line) was more than twice as high during winter $\left(2,140\right.$ individuals $\left.\mathrm{cm}^{-2}\right)$ than that observed during summer (966 individuals $\mathrm{cm}^{-2}$ ). During spring (504 individuals $\mathrm{cm}^{-2}$ ) and fall (412 individuals $\mathrm{cm}^{-2}$ ), the peak abundance of peritrichs was half than that observed during summer and one quarter of that recorded during winter. This shows a clear seasonal abundance cycle of biofilm peritrich ciliates. A similar pattern was observed for the number of zooids in the colonial species (Figure 5, orange line). These species presented more zooids during winter which led to an increase in total abundance. By contrast, $\mathrm{H}^{\prime}$ presented the highest values for both individuals and zooids during spring (individuals: $\mathrm{H}^{\prime}=1.99$, zooids: $\mathrm{H}^{\prime}=1.80$ ) and fall (individuals: $\mathrm{H}^{\prime}=1.61$, zooids: $\mathrm{H}^{\prime}=1.47$ ), while during winter (individuals: $\mathrm{H}^{\prime}=1.15$, zooids: $\mathrm{H}^{\prime}=1.38$ ) and summer (individuals: $\mathrm{H}^{\prime}=1.43$, zooids: $\mathrm{H}^{\prime}=1.40$ ), the values were relatively lower. As a general pattern, individual density was higher during winter, with a reduced diversity, indicating dominance of species.

The genera Epistylis and Vorticella were both the most diverse and abundant taxa throughout the year. There were high numbers of individuals, sometimes exceeding the total for all other genera, showing a clear dominance in competition for space. 


\section{Multiple linear regressions and cluster analysis}

Table 1 presents the RICs for cluster analysis, where species are presented in the same order as in the cluster analysis (Figure 6). Seasons within the study period presented different impacts on community structure. Summer was not significant for any species and, thus, was excluded from all analyses. Among temporal descriptors, fall was significant for four species, while successional time was a relevant parameter for five species (Table 1, RIC >0.95 or $\mathrm{RIC}<-0.95)$. Concerning environmental drivers, total phosphorous and dissolved oxygen were the most relevant parameters, causing significant response for four and three species respectively.

The pattern of species association could be more clearly revealed by a cluster analysis (Figure 6), where two major clusters can be observed. Cluster 1 differed from cluster 2 mainly in relation to seasonal effects. As a general pattern, species from cluster 1 did not present significant response to a seasonal cycle, although most of the species were negatively related to winter and spring. By contrast, most of the species in cluster 2 presented significant positive relationship (increased abundance) with season, mainly fall and spring. Concerning environmental parameters, only dissolved oxygen (DO) showed significant difference among the species from clusters 1 and 2, although at the specific level, only three species were significantly affected by this parameter.

\section{Succession in the community of peritrichs}

Table 2 presents peritrich species in relation to their constancy of occurrence, successional characteristic, number of days within a sampling period needed to reach a peak of abundance, and compound size. Figure 7 presents a scatter plot relating the compound size of each species with the number of days required to reach a peak of abundance. The graph shows that solitary species, with a total size $<500 \mu \mathrm{m}$, showed no pattern of dominance during any particular stage of succession, reaching their peaks of abundance any time during the sampling period (pioneer, secondary, and climax stages of succession).On the other hand, most of the colonial species (with exception of Epistylis sp. 4 that had a peak at the beginning of the sample period), with a total size $>500 \mu \mathrm{m}$, reached their peaks of abundance only in the last half of each sampling period (corresponding to secondary and climax stages of succession).

\section{Discussion}

The results of the present study support the hypothesis of a temporal pattern of succession in the community of peritrich ciliates that colonizes solid substrates in the Guaíba Lake, with different responses by individual species to successional time, year, season, and environmental factors. Twenty-two nominated species of peritrichs of 13 different genera were found in Guaíba Lake. In comparison with studies of other peritrich assemblages, the Guaíba Lake can be considered a highly diverse environment. For instance, Xu et al. (2009) found two species of Zoothamnium and one species of Vaginicola in a 3-month-long survey on the coast of Korea. Kusuoka and Watanabe (1987) found only four species in the genera Carchesium and Vorticella in a Japanese urban stream. Copellotti and Matarazzo (2000) recovered nine species of Vorticella and Zoothamnium during an 8-month-long survey in the lagoon of Venice (Italy), and Mieczan (2010) identified 11 species of Peritrichia in three Polish lakes, comprising only six different genera. From the few available data, Peritrichia appear to be more diverse in freshwater than in saline or estuarine areas, and increased richness could be expected for lower latitudes, a pattern already identified for aquatic fauna in general.

Epistylis and Vorticella were the most abundant genera of peritrichs and represented the highest diversity of species in the peritrich assemblage of the Guaiba Lake. Although these are not always the most abundant or common peritrich genera in water bodies (Kusuoka and Watanabe 1987; Partaly 2003), or even in periphytic communities (e.g., Gong et al. 2005), several studies have shown the importance of Vorticella and Epistylis as grazers of picoplankton (e.g., Sanders et al. 1989; Šimek et al. 1995; Macek et al. 1996; Stabell 1996). Although no direct data on bacteria abundance was obtained in the present study, the high abundance of these two genera observed during the investigation period may be due to bacteria availability, since species of Epistylis and Vorticella have been recorded as significant bacterial grazers.

Despite food abundance, a reduced number of species is usually expected in high productive water bodies due to physiological stress which results in a community dominated by a small number of very abundant species (Henebry and Ridgeway 1979; Salvado et al. 1995). The Guaíba Lake is highly impacted by wastewater discharge and is considered to have the worst quality level according to the Brazilian pollution classification system. Contrasting general patterns for Metazoa, surveys of polluted freshwater have sometimes revealed high diversity of protozoa. Small (1973) surveyed a small polluted stream in Illinois (USA) and found a total of 93 genera of ciliates, including peritrichs. Kusuoka and Watanabe (1987) also suggested that urban streams that receive domestic sewage could be considered an ideal habitat for peritrichs, owing to the high density of bacteria present in these environments. With 22 nominated species, the Guaíba Lake seems also to be very suitable for Peritrichia, probably due to high wastewater discharge and bacterial densities at the same time as dissolved oxygen is kept around $6 \mathrm{mg} \mathrm{L}^{-1}$. This occurs due to factors such as high water turnover ratio from large river inputs, 
Table 1 Relative importance coefficients for cluster analysis

\begin{tabular}{|c|c|c|c|c|c|c|c|c|c|c|c|c|}
\hline Species & Winter & Spring & Fall & $\begin{array}{l}\text { Days of } \\
\text { exposal }\end{array}$ & $\begin{array}{l}\text { Water } \\
\text { temperature }\end{array}$ & $\mathrm{pH}$ & Chlorophyll & $\begin{array}{l}\text { Total } \\
\text { solids }\end{array}$ & $\begin{array}{l}\text { Dissolved } \\
\text { oxygen }\end{array}$ & Conductivity & Turbidity & Total $\mathrm{P}$ \\
\hline \multicolumn{13}{|l|}{ Cluster 1} \\
\hline Epistylis sp. 3 & -0.947 & -0.339 & 0.412 & 0.658 & -0.887 & 0.024 & 0.696 & -0.124 & 0.519 & 0.793 & -0.239 & -0.270 \\
\hline $\begin{array}{l}\text { Thuricola } \\
\text { folliculata }\end{array}$ & -0.860 & -0.647 & 0.162 & 0.032 & -0.924 & 0.436 & 0.596 & -0.128 & 0.046 & 0.657 & -0.445 & -0.655 \\
\hline Epistylis sp. 1 & -0.298 & -0.226 & 0.697 & 0.999 & -0.265 & -0.015 & 0.507 & -0.297 & 0.202 & 0.323 & -0.105 & -0.314 \\
\hline $\begin{array}{l}\text { Opercularia } \\
\text { minima }\end{array}$ & -0.547 & -0.134 & 0.099 & 0.323 & -0.436 & -0.126 & 0.633 & 0.204 & 0.195 & -0.132 & 0.591 & -0.669 \\
\hline $\begin{array}{l}\text { Opercularia } \\
\text { racemosa }\end{array}$ & -0.920 & -0.025 & 0.708 & 1.000 & 0.369 & -0.694 & -0.192 & 0.812 & 0.977 & -0.218 & -0.102 & 0.035 \\
\hline $\begin{array}{l}\text { Vaginicola } \\
\text { tincta }\end{array}$ & -0.920 & -0.783 & 0.803 & 0.948 & -0.805 & 0.103 & 0.438 & -0.066 & 0.929 & -0.528 & -0.319 & 0.478 \\
\hline $\begin{array}{l}\text { Rhabdostyla } \\
\text { ovum }\end{array}$ & -0.358 & 0.858 & -0.263 & 0.648 & 0.113 & 0.678 & 0.480 & -0.973 & 0.536 & 0.664 & 0.928 & 0.803 \\
\hline $\begin{array}{l}\text { Vorticella } \\
\text { campanula }\end{array}$ & -0.172 & 0.192 & -0.451 & 0.350 & -0.226 & -0.050 & -0.443 & -0.897 & 0.427 & 0.838 & 0.900 & 0.035 \\
\hline $\begin{array}{l}\text { Vorticella } \\
\text { chlorostigma }\end{array}$ & -0.621 & -0.513 & -0.680 & 0.103 & 0.417 & -0.851 & 0.172 & -0.462 & 0.570 & 0.705 & 0.094 & 0.804 \\
\hline Epistylis sp. 2 & -0.793 & -0.729 & -0.238 & -0.428 & -0.764 & -0.707 & -0.113 & 0.813 & 0.519 & 0.573 & -0.160 & -0.926 \\
\hline $\begin{array}{l}\text { Vorticella } \\
\text { convallaria }\end{array}$ & -0.893 & -0.840 & -0.194 & -0.493 & -0.419 & -0.682 & 0.176 & 0.437 & 0.306 & 0.311 & 0.800 & -0.986 \\
\hline $\begin{array}{l}\text { Platycola } \\
\text { decumbens }\end{array}$ & -0.174 & -0.578 & 0.069 & -0.854 & 0.605 & 0.999 & -0.094 & 0.037 & 0.277 & -0.154 & 0.200 & -0.957 \\
\hline Pyxicola carteri & -0.936 & -0.446 & -0.163 & 0.028 & -0.098 & 0.826 & -0.118 & 0.676 & 0.929 & 0.096 & 0.211 & -0.988 \\
\hline $\begin{array}{l}\text { Vorticella } \\
\text { microstoma }\end{array}$ & -0.192 & -0.388 & -0.455 & -0.769 & -0.033 & 0.300 & -0.894 & -0.677 & 0.522 & -0.363 & 0.929 & -0.747 \\
\hline $\begin{array}{l}\text { Average cluster } \\
1\end{array}$ & -0.616 & -0.328 & 0.036 & 0.182 & -0.240 & 0.017 & 0.132 & -0.046 & 0.497 & 0.255 & 0.234 & -0.357 \\
\hline \multicolumn{13}{|l|}{ Cluster 2} \\
\hline $\begin{array}{l}\text { Carchesium } \\
\text { polypinum }\end{array}$ & -0.250 & 0.988 & 0.995 & 0.876 & 0.438 & -0.668 & 0.968 & 0.579 & 0.644 & 0.526 & -0.092 & -0.797 \\
\hline Epistylis sp. 4 & 0.723 & 0.619 & 0.978 & 0.997 & 0.261 & -0.397 & 0.486 & 0.324 & -0.542 & 0.444 & -0.833 & -0.412 \\
\hline $\begin{array}{l}\text { Opercularia } \\
\text { elongata }\end{array}$ & 0.498 & 0.975 & 0.931 & 0.955 & 0.881 & -0.356 & -0.249 & 0.160 & 0.813 & -0.624 & -0.165 & -0.181 \\
\hline $\begin{array}{l}\text { Epistylis } \\
\text { plicatilis }\end{array}$ & 0.997 & 0.778 & 0.769 & 0.701 & 0.460 & -0.019 & -0.412 & 0.712 & -0.996 & -0.767 & -0.732 & 0.363 \\
\hline $\begin{array}{l}\text { Haplocaulus } \\
\text { distinguendus }\end{array}$ & 0.246 & 0.722 & 0.436 & -0.085 & -0.071 & 0.500 & 0.630 & -0.561 & 0.026 & 0.156 & 0.545 & -0.807 \\
\hline $\begin{array}{l}\text { Myoschiston } \\
\text { duplicatum }\end{array}$ & -0.641 & 0.856 & 0.866 & 0.310 & 0.745 & 0.743 & 0.375 & 0.107 & 0.529 & 0.923 & 0.871 & -0.856 \\
\hline $\begin{array}{l}\text { Cothurnia } \\
\text { annulata }\end{array}$ & 0.927 & 0.150 & 0.967 & 0.005 & -0.282 & 0.513 & -0.900 & -0.231 & -0.824 & 0.214 & 0.776 & -0.880 \\
\hline $\begin{array}{l}\text { Zoothamnium } \\
\text { arbuscula }\end{array}$ & 0.872 & 0.096 & 0.989 & -0.985 & -0.706 & -0.849 & 0.590 & -0.582 & -0.963 & -0.385 & 0.629 & -0.983 \\
\hline $\begin{array}{l}\text { Average cluster } \\
2\end{array}$ & 0.421 & 0.648 & 0.866 & 0.347 & 0.216 & -0.067 & 0.186 & 0.063 & -0.164 & 0.061 & 0.125 & -0.569 \\
\hline$t$ test $(p)$ & 0.001 & 0.000 & 0.000 & 0.586 & 0.070 & 0.756 & 0.836 & 0.645 & 0.045 & 0.444 & 0.696 & 0.294 \\
\hline
\end{tabular}

$\mathrm{RIC}=(1-P) \times B / \bmod (B)$, where $P$ is the significance value for each regression coefficient $B$, and mod represents the modulus of the $B$ value as estimated by multiple linear regression coefficients relating to peritrich species abundance (standardized (In +1 ) values) with seasons and water quality parameters (significant values are italicized, $P<0.05$ ). Data obtained between June 2010 and June 2011 for Guaíba Lake, southern Brazil. Species are presented in the same order as in the cluster analysis (Figure 5). $t$ test compares species from clusters 1 and 2. 


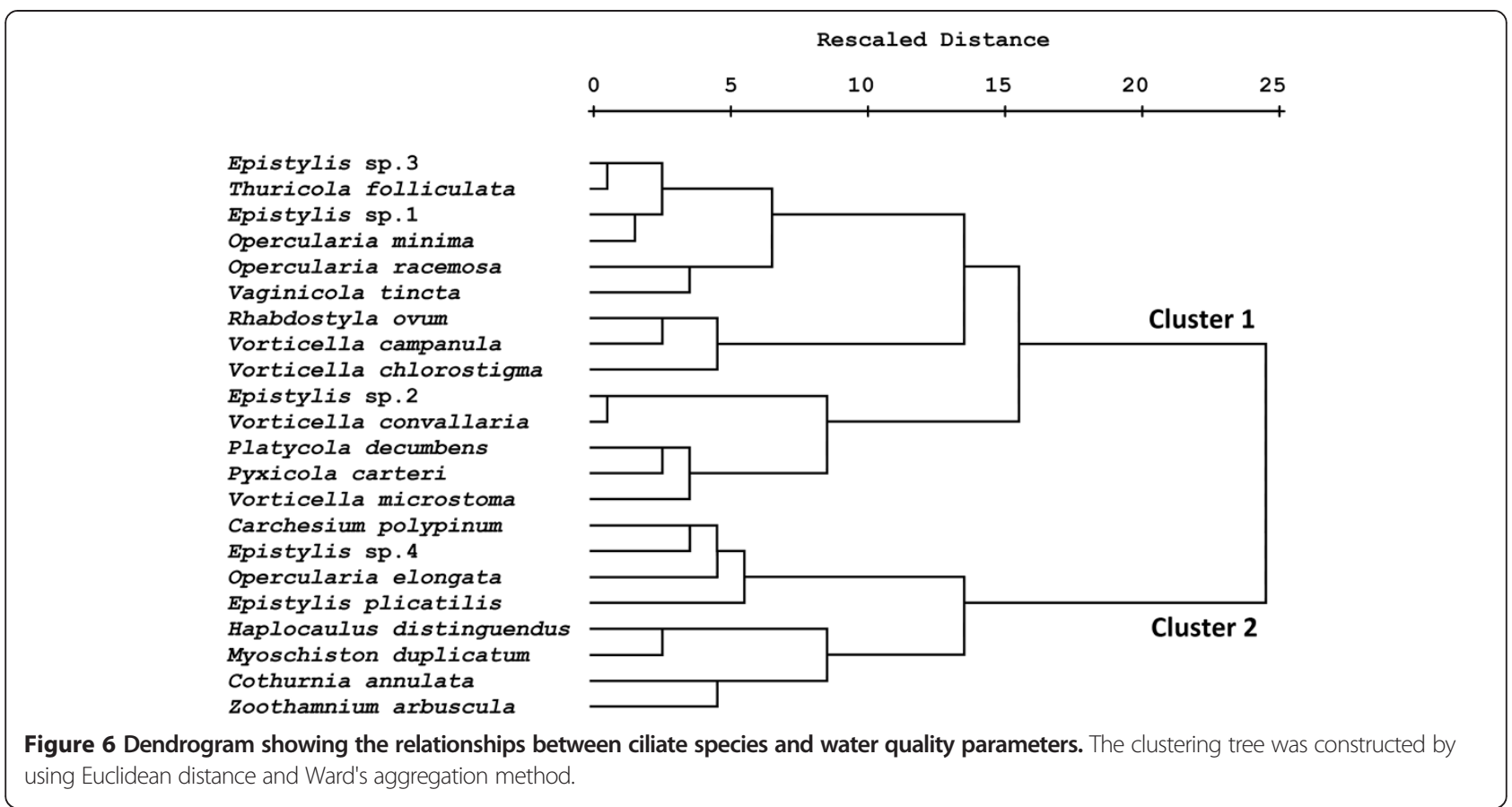

relatively small depth, and constant winds that favor gas exchange and vertical water circulation.

Among the measured environmental parameters and considering the variation amplitude in the Guaíba Lake, temperature, conductivity, and turbidity were not significant environmental drivers for any species, while $\mathrm{pH}$, chlorophyll $a$, and total solids were relevant drivers for just one species (Table 1 , RIC $>0.95$ or RIC $<-0.95$ ). On the other hand, total phosphorous and dissolved oxygen were significant for four and three species, respectively, suggesting an abundance pattern related to nutrient availability and its impact on dissolved oxygen.

Despite the lower metabolic rates that could be inferred from lower temperatures during winter, there was a particularly higher abundance of individuals and zooids. During this season, the lake receives a high influx of water (increased rainfall and reduced evapotranspiration) that probably helps dilute pollutants, leading to an improvement of the water quality by diluting human sewage with increased water flow. Although loosely correlated to conductivity and chlorophyll $a$ if considered the second component of the PCA (Figure 3), winter presents a secondary negative relationship (component 2) with total phosphorous, turbidity, and total solids, all indicators of poor water quality. Studies on periphytic communities in other environments have shown an opposite result. For example, Beech and Landers (2002) in a survey of ciliates colonizing artificial substrates in Dauphin Island found a significant decline in populations of peritrichs and suctorians during winter. In this regard, a comparison with less polluted or nonpolluted areas would help understand the influence of pollutants on the growth of these organisms, as the population responses could be the result of synergic and antagonist effects of several environmental drivers. Although our original purpose was to identify these drivers, our sampling design fail to show a complete framework of interactions, probably due to limited time and space scale that restricted variable covariation.

Density of peritrichs at the study site varied markedly over time. In general, there were some periods of severe reduction in abundance in all seasons, but it is not clear whether these represent a successional cycle, recovery from catastrophic events, or the result of natural variability in sampling. In general, ciliate densities are often positively correlated with increasing food supplies, which suggests that abundance is resourcelimited (Fenchel 1968). Moreover, experimental work has demonstrated that ciliate assemblages also may be strongly affected by direct metazoan interactions (Jack and Gilbert 1993; Wickham and Gilbert 1993). These interactions can be predation, mechanical interference, or both. Masclaux et al. (2012) demonstrated that the cladoceran Eurycercus lamellatus feeds exclusively on periphyton. Arndt (1993) has also observed that large grasping rotifer species could feed on ciliates, especially peritrichs that they could dislodge from the stalk. This ability of small invertebrates to graze on periphytic organisms would lead to fluctuations in a periphyton community. In the present work, some reductions in density were followed by reductions in species richness, suggesting a severe impact of some sort on the community. This impact could be predation by invertebrates since rotifers, 
Table 2 List of peritrich species sampled in Lake Guaíba (southern Brazil)

\begin{tabular}{|c|c|c|c|c|}
\hline Species & Constancy of occurrence & Successional characteristic & Abundance peak (days) & Compound size $(\mu \mathrm{m})$ \\
\hline Carchesium polypinum & Constant & Secondary & 60 & 734.3 \\
\hline Cothurnia annulata & Constant & Secondary & 50 & 150.1 \\
\hline Epistylis plicatilis & Accessory & Pioneer & 10 & 364.1 \\
\hline Epistylis sp. 1 & Casual & Climax & 90 & 972.6 \\
\hline Epistylis sp. 2 & Casual & Climax & 90 & $1,124.5$ \\
\hline Epistylis sp. 3 & Casual & Climax & 80 & 967.1 \\
\hline Epistylis sp. 4 & Casual & Pioneer & 5 & 661.1 \\
\hline Haplocaulus distinguendus & Casual & Secondary & 60 & \\
\hline Myoschiston duplicatum & Constant & Pioneer & 30 & 358.1 \\
\hline Opercularia elongata & Casual & Climax & 90 & 307.1 \\
\hline Opercularia minima & Accessory & Secondary & 70 & 140.1 \\
\hline Opercularia racemosa & Accessory & Secondary & 90 & 213.8 \\
\hline Platycola decumbens & Casual & Pioneer & 30 & 204.0 \\
\hline Pyxicola carteri & Constant & Climax & 70 & 140.1 \\
\hline Rhabdostyla ovum & Casual & Pioneer & 30 & \\
\hline Thuricola folliculata & Casual & Secondary & 80 & \\
\hline Vaginicola tincta & Casual & Secondary & 40 & \\
\hline Vorticella campanula & Constant & Secondary & 50 & 566.5 \\
\hline Vorticella chlorostigma & Casual & Pioneer & 10 & 157.5 \\
\hline Vorticella convallaria & Constant & Secondary & 50 & 234.4 \\
\hline Vorticella microstoma & Constant & Secondary & 40 & 394.6 \\
\hline Zoothamnium arbuscula & Casual & Pioneer & 30 & \\
\hline
\end{tabular}

The species are classified according to their constancy of occurrence, successional characteristic, days of exposure that presented the highest density, and compound size (sum of the mean zooid length, mean zooid width at midpoint, mean basal stalk length, and mean basal stalk width; in micrometers). Species present in more than $50 \%$ of collections were named as constant, those between $25 \%$ and $49 \%$ were considered accessory, and those occurring in less than $25 \%$ were named casual. Pioneer species were considered those whose maximum occurrences were recorded by the 30th day of exposure of the traps in the water; secondary species were those that had their maximums between the 30th and 60th days of exposure, and climax were considered the species that presented maximum occurrence after the 60th day of exposure.

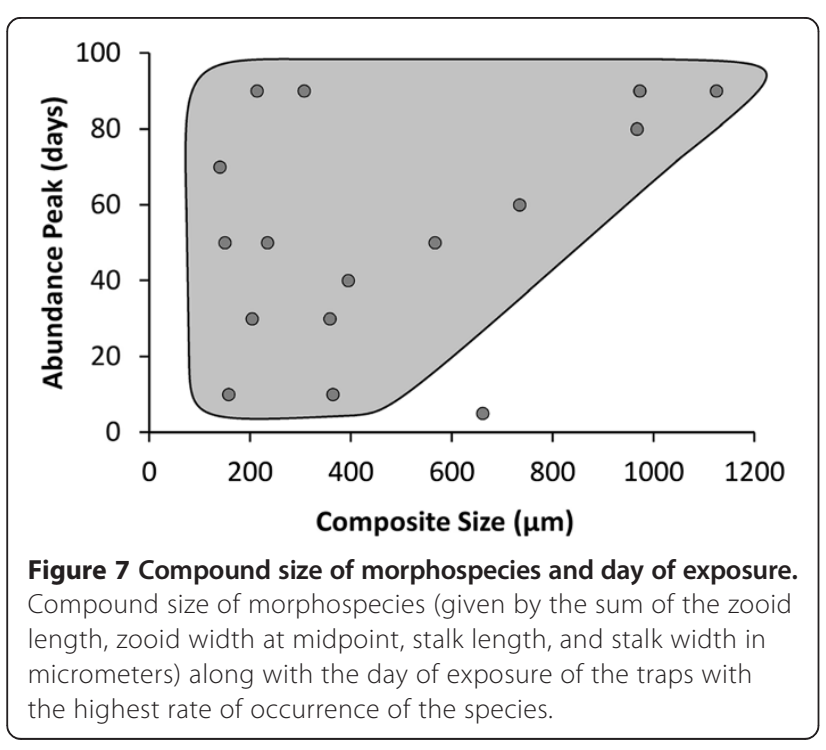

cladocerans, and insect larvae were frequently found in the samples.

Müller et al. (2012), in a series of experiments with Paramecium bursaria and Colpidium striatum, showed that planktonic, free-living ciliates may generate interference interactions relative to one another, such as biochemical-mediated interactions and allelopathy. A similar experimental setup has never been applied to sessile ciliates, although the same kind of interaction may be possible to be happening among ciliates that are part of a periphytic community. The species of peritrichs in the present study showed differences in their successional patterns, and at the end of each season, late colonizers were dominant on the surfaces of glass slides. These late colonizers that generally presented large colonies and zooids may be capable of dislodging smaller-sized peritrichs, generating an interference competition that could affect food acquisition and lead to space loss. Laboratory 
experiments with early and later colonizers are needed to test this hypothesis.

Most of our knowledge on successional patterns in aquatic habitats comes from studies on benthic invertebrates. For instance, Hirata (1987) investigated the succession of marine invertebrates, including barnacles, ascidians, and oysters, and observed that biological characteristics of the species could influence their occurrence and successional cycles. He also inferred that species succession could be governed in some cases by historical differences in colonization and disturbance that lead to changes in species dominance observed at different successional stages. Breitburg (1985), on the other hand, suggested that the most important factors determining species succession are the interactions between the organisms and not between successional stages.

In this regard, the presence of early colonizers could affect recruitment of peritrichs, promoting the establishment of other species that, in general, are stronger competitors. This trend was observed in the present study, where species of peritrichs in the first half of a sampling period did not show a definite size pattern, but those in the second half tended to be larger species (compound size: sum of the zooid length, zooid width at midpoint, stalk length, and stalk width). Larger species of peritrichs may be better competitors for space, but may depend on the presence of the early colonizers in some way. In addition to interactions among species that might govern succession, there is also the possible influence of environmental factors on the successional dynamics, leading to a complex system depending on interconnecting relationships that need to be explored much more thoroughly.

\section{Conclusions}

A temporal pattern of succession in the community of peritrich ciliates that colonizes solid substrates in the Guaíba Lake was clearly demonstrated, with different responses by individual species to successional time, year, season, and environmental factors. The peritrich community in the studied area was highly diverse in comparison with other freshwater environments in higher latitudes, a pattern already identified for aquatic fauna in general. The high abundance displayed during winter may reflect a high influx of water that helps dilute pollutants, favoring the growth of these ciliates, while the density fluctuation observed over time may be correlated to the occurrence of grazers. In short, successional patterns in peritrich communities may be governed by species interaction as well as environmental factors. The results obtained here are a starting point to a better understanding of the complex interactions that govern these periphytic communities.

\section{Competing interests}

The authors declare that they have no competing interests.

\section{Authors' contribution}

LSLS collected the data and helped draft the manuscript. NFF participated in the conception of the study and in its design, performed the statistical analyses, and helped draft the manuscript. HJS helped with data collection. LRPU participated in the conception of the study and in its design and helped draft the manuscript. All authors read and approved the final manuscript.

\section{Acknowledgements}

We thank the colleagues from the Aquatic Ecology Laboratory for their critical review and assistance in laboratory procedures, especially Thiago Silveira for his assistance with figure elaboration. We also thank Dr. John Clamp, Dr. Luiz Felipe Velho, and Dr. Alan Warren for their valuable comments on the earlier version of this manuscript. We also thank two anonymous reviewers for their valuable comments that helped improve the manuscript. This study was supported by a scholarship from CAPES granted to the first author.

Received: 18 December 2013 Accepted: 21 March 2014

Published online: 29 April 2014

\section{References}

Andrushchyshyn O, Magnusson AK, Williams DD (2003) Ciliate populations in temporary freshwater ponds: seasonal dynamics and influential factors. Freshwater Biol 48:548-564

Beaver JR, Chrisman TL (1989) The role of ciliated protozoa in pelagic freshwater ecosystems. Micr Ecol 17:111-136

Beech CD, Landers S (2002) Ciliated protozoan colonization of substrates from Dauphin Island, Alabama. Eur J Protistol 38:83-89

Bendati MM, Schwarzbach MSR, Maizonave CRM, Almeida LB, Bringhenti ML (2000) Avaliação da qualidade da água do lago Guaíba (Rio Grande do Sul, Brasil) como suporte para a gestão da bacia hidrográfica. In Anais do XXVII Congresso Interamericano de Engenharia Sanitária e Ambiental. Associação Interamericano de Engenharia Sanitária e Ambiental, Porto Alegre, Brasil, pp 1-20

Breitburg DL (1985) Development of a subtidal epibenthic community: factors affecting species composition and the mechanisms of succession. Oecologia 65:173-184

Carrias JF, Cussac ME, Corbara B (2001) A preliminary study of freshwater protozoa in tank bromeliads. J Trop Ecol 17:611-617

Copellotti O, Matarazzo P (2000) Ciliate colonization of artificial substrates in the Lagoon of Venice. J Mar Biol Assoc UK 80:419-480

Corliss JO (1979) The ciliated protozoa: characterization, classification, and guide to the literature. Pergamon, New York

Dagget PM, Nerad TA (1992) Cultivation of selected peritrichs. In: Lee JJ, Soldo AT (eds) Protocols in protozoology. Society of Protozoologists, Lawrence, A-14.1

Fenchel T (1968) The ecology of marine microbenthos II: the food of marine benthic ciliates. Ophelia 5:73-121

Foissner W, Berger H, Kohnmann F (1992) Taxonomische und ökologische revision der ciliaten des saprobiensystems. Band II: Peritrichia, Heterotrichida, Odontostomatida. Bayerrisches Landesamt für Wasserwirtschaft, Munchen

Gong J, Song W, Warren A (2005) Periphytic ciliate colonization: annual cycle and responses to environmental conditions. Aquat Micr Ecol 39:159-170

Henebry MS, Ridgeway BT (1979) Epizoic ciliated protozoa of planktonic copepods and cladocerans and their possible use as indicators of organic water pollution. Trans Am Micr Soc 98:495-508

Hirata T (1987) Succession of sessile organisms on experimental plates immersed in Nabeta Bay, Izu Peninsula. Japan Mar Ecol 38:25-35

Jack JD, Gilbert JJ (1993) The effect of suspended clay on ciliate population growth rates. Freshwat Biol 29:385-394

Jack JD, Gilbert JJ (1997) Effects of metazoan predators on ciliates in freshwater plankton communities. J Euk Mic 44:194-199

Kahl A (1935) Urtiere oder protozoa l: wimpertiere oder ciliata (infusoria), 4: peritricha und chonotricha. In: Dahl F (ed) Die tierwelt Deutschlands. G. Fischer, Jena

Kusuoka Y, Watanabe Y (1987) Growth and survival of peritrich ciliates in an urban stream. Oecologia 73:16-20

Li L, Song W, Warren A, Shin MK, Chen Z, Ji D, Sun P (2008) Reconsideration of the phylogenetic positions of five peritrich genera, Vorticella, Pseudovorticella, 
Zoothamnopsis, Zoothamnium and Epicarchesium (Ciliophora, Peritrichia, Sessilida), based on small subunit rRNA gene sequences. J Euk Mic 55:448-456

Lynn DH, Small EB (2000) Phylum Ciliophora. In: Lee JJ, Leedale GF, Bradburry P (eds) An illustrated guide to the Protozoa Society of Protozoologists. Protozoa Society of Protozoologists, Lawrence, pp 371-656

Macek M, Šimek K, Pernthaler J, Vyhnálek V, Psenner R (1996) Growth rates of dominant planktonic ciliates in two freshwater bodies of different trophic degree. J Plank Res 18:463-481

Masclaux H, Bec A, Bourdier G (2012) Trophic partitioning among three littoral microcustaceans: relative importance as periphyton as food resource. J Limnol 71:261-266

Mieczan T (2010) Periphytic ciliates in three shallow lakes in Eastern Poland: a comparative study between a phytoplankton-dominated lake, a phytoplankton-macrophyte lake and a macrophyte-dominated lake. Zool Studies 49:589-600

Montagnes DJS, Lynn DH (1987) A quantitative Protargol stain (QPS) for ciliates: method description and tests for its quantitative nature. Mar Micr Food Webs 2:83-93

Müller JP, Hauzy C, Hulot FD (2012) Ingredients for protist coexistence: competition, endosymbiosis and a pinch of biochemical interactions. J An Ecol 81:222-232

Partaly YM (2003) Peculiarities of successions in biocenoses of fouling in the Sea of Azov. Hydrobiol J 29:103-112

Rossato MS, Martins RL (2001) Foz do Iguaçu. In: Epiphanio JC, Galvao LS (eds) X SBSR: anais. SBSR, Sao Paulo, pp 971-974

Salomoni SE, Torgan LC (2008) Epilithic diatoms as organic contamination degree indicators in Guaíba Lake, Southern Brazil. Acta Limnol Bras 20:313-324

Salvado H, Gracia MP, Amigó JM (1995) Capability of ciliated protozoa as indicators of effluent quality in activated sludge plants. Water Res 29:1041-1050

Sanders RW, Porter KG, Bennett SJ, Debiase AE (1989) Seasonal patterns of bacterivory by flagellates, ciliates, rotifers, and cladocerans in a freshwater planktonic community. Limnol Oceanogr 34:673-687

Šimek K, Bobkova J, Macek M, Nedoma J (1995) Ciliate grazing on picoplankton in a eutrophic reservoir during the summer phytoplankton maximum: a study at the species and community level. Limnol Oceanogr 40:1077-1090

Small EB (1973) A study of ciliate protozoa from a small polluted stream in east-central Illinois. Am Zool 13:225-230

Stabell T (1996) Ciliate bacterivory in epilimnetic waters. Aquat Microbiol 10:265-272

Utz LRP (2007) First record of Epistylis plicatilis (Ciliophora: peritrichia) attached to Pomacea canaliculata (Mollusca: Gastropoda) in Southern Brazil. Zootaxa 1454:49-57

Utz LRP, Coats DW (2008) Telotroch formation, survival, and attachment in the epibiotic peritrich Zoothamnium intermedium (Ciliophora, Oligohymenophorea). Inv Biol 127:237-248

Warren A (1982) A taxonomic revision of the genus Platycola (Ciliophora: Peritrichida). Bull Brit Mus Zool 43:95-108

Warren A (1986) A revision of the genus Vorticella (Ciliophora: Peritrichida). Bull Brit Mus Zool 50:1-57

Warren A (1991) A revision of the Cothurnia (Ciliophora: peritrichida) and it's morphological relatives. Bull Brit Mus Zool 57:17-59

Wetzel RG (2001) Limnology: lake and river ecosystems. Academic, San Diego

Wey JK, Scherwass A, Norf H, Arndt H, Weitere M (2008) Effects of protozoan grazing within river biofilms under semi-natural conditions. Aquat Microb Ecol 52:283-296

Wickham SA, Gilbert JJ (1993) The predatory behavior of Mesocyclops edax: predator preference, prey defenses and starvation induced changes. Limnol Oceanogr 25:903-909

Xu H, Min G, Choi JK, Kim S, Jung J, Lim B (2009) An approach to analyses of periphytic ciliate communities for monitoring water quality using a modified artificial substrate in Korean coastal waters. J Mar Biol Assoc UK 89:669-679

Xu H, Choi J, Min G, Zhu Q (2011) Colonization dynamics of periphytic ciliate communities across taxonomic levels using an artificial substrate for monitoring water quality in coastal waters. J Mar Biol Assoc UK 91:91-96

Zingel P, Nõges T (2010) Seasonal and annual population dynamics of ciliates in a shallow eutrophic lake. Fund Appl Limnol 176:133-14

doi:10.1186/s40555-014-0017-3

Cite this article as: Safi et al:: Temporal structure of the peritrich ciliate assemblage in a large Neotropical lake. Zoological Studies 2014 53:17.

\section{Submit your manuscript to a SpringerOpen ${ }^{\circ}$ journal and benefit from:}

- Convenient online submission

- Rigorous peer review

- Immediate publication on acceptance

- Open access: articles freely available online

- High visibility within the field

- Retaining the copyright to your article

Submit your next manuscript at $\gg$ springeropen.com 